Pamiętnik Literacki 2020, 3, s. 21-37

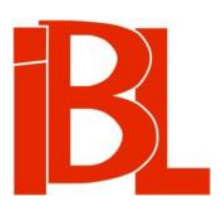

\title{
Idea epopei żałobnej. Późna twórczość Wincentego Pola w świetle „Pacholęcia hetmańskiego"
}

Damian Włodzimierz Makuch 


\section{IDEA EPOPEI ŻAEOBNEJ PÓŹNA TWÓRCZOŚĆ WINCENTEGO POLA W ŚWIETLE „PACHOLĘCIA HETMAŃSKIEGO”}

Zarówno wśród pierwszych krytyków, jak i wśród późniejszych badaczy dominowało przekonanie, że Pacholę hetmańskie Wincentego Pola, choć nie pozbawione pewnych zalet, to utwór nieudany, chaotyczny i wtórny ${ }^{1}$. Autor skupił się w nim na postaci Jana Tarnowskiego, hetmana wielkiego koronnego, którego sportretował za pośrednictwem diariusza pisanego przez Walentego Rożankę - tytułowego bohatera, wychowywanego na magnackim dworze. Współczesny Polowi czytelnik, obyty $\mathrm{z}$ jego twórczością, odnajdywał w poemacie problemy i motywy dobrze już znane $z$ lektury innych dzieł autora. W Pacholęciu hetmańskim idealizuje się bowiem szlachtę, mityzuje przeszłość (XVI i XVII w.), gloryfikuje religijność, sakralizuje lokalną ojczyznę (okolice Sandomierza) i z geograficznym zacięciem opisuje tzw. Kresy czy Ziemię Świętą.

Powtarzalność tematyczna i formalna późnych utworów Pola ${ }^{2}$ sprawiła, że krytycy i badacze nawet nie próbowali dopatrywać się w poemacie z 1862 r. znamion rewolucji artystycznej. Sam autor uważał jednak swoje dzieło za nowatorskie i przełomowe, co więcej - traktował je jako punkt zwrotny w swojej dotychczasowej twórczości. Warto się zastanowić, dlaczego akurat Pacholę hetmańskie stało się przyczyną nieporozumienia interpretacyjnego i dlaczego to nieporozumienie utrzymywało się tak długo. Szczególnie interesujący wydaje mi się problem świadomości metaliterackiej Pola: jego intencji, które dla egzegetów okazały się nieczytelne. Wyjaśniając to nieoczekiwane fiasko interpretacyjne, chciałbym pokazać, jak zmieniał się język dyskursu krytycznoliterackiego w latach sześćdziesiątych XIX stulecia, i zaprezentować trzy dopełniające się klucze interpretacyjne, które pozwolą na nowo zrozumieć późną twórczość Pola.

$1 \quad$ W. Pol, Pacholę hetmańskie. T. 1-2. Warszawa 1862. Recepcję poematu zwięźle przedstawiła W. B ryła (Syn ziemian i rycerzy. Studia o twórczości i języku Wincentego Pola. Lublin 2016, s. 137-140). Przedmiotem badań literaturoznawców bywały też poszczególne sceny i motywy utworu Pola - zob. M. Łoboz, Śpiewak pieśni niedogranych. W kręgu twórczości Wincentego Pola. Wrocław 2004, s. 112-113.

2 Przez późna twórczość rozumiem w tym wypadku dzieła powstałe po r. 1855, a więc po śmierci żony pisarza, Kornelii. 


\section{Niedoczytanie pierwsze - idea i forma}

Idea Pacholęcia hetmańskiego zrodziła się w r. $1855^{3}$, ale utwór ukazał się dopiero w lipcu 1862. Większość badaczy zakładała, że przez tych siedem lat tekst przeleżał w szufladzie autora, tymczasem znajdował się on u ks. Jana Scipiona del Campo, jednego z pierwszych skrybów ślepnącego Pola. W kwietniu 1859, dzięki usilnym staraniom Szymona Dutkiewicza, przyjaciela i pełnomocnika pisarza w sprawach wydawniczych, rękopis wrócił do autora ${ }^{4}$. Ale nawet wówczas, z powodu licznych kłopotów Pola (próby wyratowania syna od służby wojskowej, budowa domu, walka o prawa autorskie do dzieł publikowanych w Królestwie Kongresowym), prace nad poematem prawie nie postępowały - nic więc dziwnego, że Maurycy Mann nie wymienił go wśród utworów kończonych i przepisywanych w pierwszych miesiącach 1860 roku $^{5}$. Jak wynika z zachowanej korespondencji, Pol nie dysponował wtedy zasadniczą większością tekstu, a część już powstałą postrzegał jako obca i wymagająca zmian ${ }^{6}$. Wprawdzie redakcja „Biblioteki Warszawskiej” pod koniec 1860 r. zapewniała, że autor "ma gotowy poemat [...] z czasów ostatniego Jagiellończyka", i na dowód cytowała fragment dzieła uprzednio wydrukowany w zaprzyjaźnionym „Kółku Rodzinnym”, ale na początku następnego roku Pol informował przyjaciól, przepisywaczy i wydawców, że właśnie finalizuje księgę czwartą, „trzeciej ukończyć, a drugiej poczaćc nie ma odwagi, bierze się więc do pisania piątej, ostatniej ${ }^{8}$. W pierwszym kwartale 1861 r. dyktowany poemat wciąż się rozrastał, przy czym ogłoszone w prasie fragmenty nie zostały włączone do poszczególnych ksiąg. Tekst ukonstytuował się w kwietniu 1861 w Przemyślu, miejscu odosobnienia, do którego Pol, zrażony krytyką wywołaną przez Listy spod Lwowa Kornela Ujejskiego ${ }^{9}$, uciekł we wrześniu $1860 \mathrm{z} \mathrm{Lu-}$ bienia, gdzie późną wiosną i przez całe lato organizowano męczące poetę obiady $\mathrm{ku}$ jego $\mathrm{Czci}^{10}$.

To krótkie zestawienie dat pokazuje okoliczności powstania Pacholęcia hetmań-

3 Wzmianka o rozpoczęciu pracy nad nowym utworem znajduje się liście W. Po la do syna (W. Pola jun.) z 8 II 1855 (w: Listy z ziemi naszej. Korespondencja Wincentego Pola z lat 1826-1872. Zebrał, oprac., wstęp Z. Sudolski. Warszawa 2004, s. 269 (do edycji tej odsyłam dalej za pomoca skrótu L, po którym podaję numery stronic $\rangle$ ).

4 Zob. W. Po l, list od Sz. Dutkiewicza, z 31 III, 5-8 IV 1859. L 594. Przyjaźni z Dutkiewiczem przyglądał się w swojej monografii M. Mann (Wincenty Pol. Studium biograficzno-krytyczne. T. 2. Kraków 1906, s. 181-185).

5 M a n n (op. cit., s. 446-448) wskazał na finalizowanie innych dzieł, które ostatecznie ukazały się po Pacholęciu hetmańskim - takich jak Pieśń o domu naszym (Lwów 1866) czy Rok myśliwca (Poznań 1870; wcześniej, w r. 1866, na łamach „Tygodnika Ilustrowanego” (nry 344-368〉).

6 W. Pol, listy do Sz. Dutkiewicza, z 8 X 1859 i z 29 XI 1860. L 341, 367.

7 „Biblioteka Warszawska” 1860, t. 4, s. 678 (rubryka Wiadomości literackie). - W. P o 1, Jako pan Maruszka tu żył po śmierci hetmana. Jw., s. 678-681 (pierwodruk: Jako pan Maruszka Zaleski tużyt po śmierci Hetmana. Rapsod z „Pacholęcia hetmańskiego”. „Kółko Rodzinne” 1860, nr 12, z 22 V).

8 W. Pol, list do Sz. Dutkiewicza, z 4 II 1861. L 374.

9 Chodzi oczywiście o oskarżycielski tekst K. Uje j s ki e go O Januszu i o panu Wincentym, publikowany na łamach „Dziennika Literackiego” przez pięć tygodni począwszy od 8 V 1860 (nry 34-46). Wszedł on następnie do tomu Listy spod Lwowa. Pierwsze trzy głosy (Lwów 1860). 
skiego. Warto podkreślić, że dzieło uzyskało ostateczny kształt zaraz po atakach, które spadły na Pola w związku z surowym wystapieniem Ujejskiego i z odpowiedziami na nie ${ }^{11}$, a także podczas manifestacji przedstyczniowych w Warszawie ${ }^{12}$. Po listownej samoobronie adresowanej do Józefa Keniga, redaktora naczelnego „Gazety Warszawskiej” ${ }^{13}$, był to pierwszy tekst literacki, w którym Pol mógł udowodnić niesłuszność stawianych mu zarzutów; wcześniej poeta nawet w stosunkach towarzyskich wybierał „strategie sfinksa” - milczenie ${ }^{14}$.

Pogrążony w żalu i zwątpieniu autor „na nowo, od początku, po upływie lat sześciu [od przerwania pracy nad poematem]” próbował rozniecić w sobie zapał twórczy, przebudowując i znacznie rozszerzając już napisane fragmenty poematu ${ }^{15}$. Co istotne, przywoływanie postaci hetmana postrzegał nie tyle jako ucieczkę w krainę przeszłości, eskapistyczne łagodzenie „ucisku duszy” ${ }^{16}$, ile jako najtrudniejszy wysiłek literacki ${ }^{17}$, umożliwiajacy rozrachunek $\mathrm{z}$ opinią publiczną: „Piszę Pacholę hetmańskie i jeżeli mi Bóg tę pracę ukończyć dozwoli, zdaje mi się, że się uspokoję w duchu po jej ukończeniu i odprawię rzeczy światowe, czego tak bardzo pragnę!"18. Pol wielokrotnie nazywał poemat swoim ostatnim dziełem i zapowiadał, że po jego ukończeniu zamierza pożegnać się z zawodem literata - wszystko w związku z nową oceną własnej kondycji pisarskiej, chyba najlepiej wyrażoną w liście do Juliusza Kossaka: „Jesteśmy oba podobni do tych budowniczych, co ostatnie gotyckie wznosili kościoły i z którymi tajemnica ich twórczości i sztuki zstąpiła do grobu. W tym przekonaniu i uczuciu napisałem Pacholę hetmańskie"19.

Ambicje Pola były czytelne dla jego bliskich, ale nawet oni nie potrafili przeniknać architektoniki „ostatniego” dzieła, jakim miało być Pacholę hetmańskie ${ }^{20}$. Wiele światła na sens poematu rzuca rozproszony dialog Wincentego Pola z Eleonorą Ziemięcką, zapoczątkowany przez jej recenzję ${ }^{21}$.

Autorka Zarysów filozofii katolickiej, zwykle uważana za wyjątkowo konserwa-

11 Przebieg tych wydarzeń został już dobrze zbadany, dlatego nie zajmuję się nim szczegółowo. Zob. np. J. Ro s n ow s k a, Dzieje poety. O Wincentym Polu. Warszawa 1963, s. 341-345. - J. B a c h ó r z, Miejsce Wincentego Pola w polskiej literaturze dziewiętnastowiecznej. W zb.: Wincentego Pola fascynacje literatura i krajobrazem. Red. T. Pi ersiak, A. Ti m of i j j w. Lublin 2010. - S. Fi t a, Wincenty Pol w oczach pozytywistów. W zb.: jw. - M. U r s e 1, Wizerunek Wincentego Pola w świetle prasy polskiej $w$ drugiej połowie XIX wieku. W zb.: Obrazy natury i kultura. Studia o Wincentym Polu. Red. M. Łoboz. Wrocław 2015.

Zob. np. W. P ol, list do P. Moszyńskiego, z 11 I 1861. L 372.

W. Pol, list do J. Keniga, z 4 VI 1860. L 360-363.

Określenie W. Pola (list do K. Miączyńskiej, z 30 VIII 1860. L 367). Zob. też Ma n n, op. cit., s. 455-456.

Pol, list do Dutkiewicza, z 29 XI 1860. L 367-368.

W. Pol, list do ks. I. Isakowicza, z 19 X 1861. L 379.

Widać to zwłaszcza w Przedsionku, poetyckiej apostrofie do duchów przeszłości, które Pol prosi o możliwość ostatniego wejrzenia w dawny świat. Fragment ten nie wszedł do poematu, znamy go jedynie $z$ listu Pola do Dutkiewicza (z 29 XI 1860. L 367-368).

W. Pol, list do ks. A. Prusinowskiego, z 2 I 1861. L 371.

W. Pol, list do J. Kossaka, z 25 IV 1862. L 382-383.

20 Później jako „ostatnią” poeta określał też Pieśń o domu naszym. Zob. W. P o 1, list do T. Krasickiej, z 20 II 1867. L 426.

21 E. Zi e m i ę c k a, Rzut oka na nowy utwór Wincentego Pola pt. „Pacholę hetmańskie”. „Noworocznik (Kalendarz) Ilustrowany dla Polek”. Na rok 1864. 
tywną teoretyczkę myśli religijnej ${ }^{22}$, dobrze znała się z Polem (była jego korespondentką związana z kręgiem literatów skupionych wokół Antoniego Edwarda Odyńca) i wielokrotnie odwoływała się do jego twórczości. Część króciutkich opowiadań z Powiastek ludowych wydawanych w trudnym dla niego roku 1860 - których serię pierwszą zadedykowała poecie w „dowód uwielbienia i przyjaźni” - Ziemięcka poprzedziła mottami $z$ jego wierszy i poematów; ich fragmenty wplatała też zreszta w teksty opowiadań z tomu. Polowi poświęciła swój najciekawszy tekst krytyczny o kursach Mickiewicza - opublikowany w Studiach, gdzie znalazło się także opracowanie kategorii liryzmu, której najlepszym wcieleniem wydawała się Ziemięckiej właśnie poezja Pola, ponieważ - jak pisała - jego intymną „spowiedź psychiczną” można wykorzystać jako „konieczny element oświaty narodowej”"23. Do poety kierowała też prośby o polecenie lektur i o informacje na temat galicyjskiego środowiska filozoficznego ${ }^{24}$.

Sam Pol również wysoko cenił Ziemięcką, i to nie tylko jako przyjaciółkę (którą często pozdrawiał w listach do Odyńca i która zapraszał na swoje prelekcje), ale też jako wnikliwą myślicielkę. W jego korespondencji z okresu lwowskich wykładów o literaturze (prowadzonych od stycznia 1864) i muzyce kościelnej (od stycznia 1865) jawi się ona jako ważna, bo kompetentna adresatka. To jej zawdzięczał poeta wsparcie merytoryczne niezbędne do przygotowania wykładu dziesiątego z Pamiętnika do literatury polskiej XIX wieku ${ }^{25}$ i jej tłumaczył w liście ideę przewodnia kursu o muzyce kościelnej, przypominając zarazem warszawskie spotkania i wychwalając zalety umysłu filozofki ${ }^{26}$.

Właśnie w czasie tych ożywionych kontaktów, wynikających z przekonania o wspólnocie poglądów oraz o podobnym postrzeganiu kultury i sztuki, Ziemięcka opublikowała obszerny szkic poświęcony Pacholęciu hetmańskiemu. Za punkt wyjścia przyjęła zarysowanie szerokiej panoramy historiozoficznej, na której tle, w duchu chrześcijańskiego uniwersalizmu, chciała pojednać ludzi tradycji i ludzi postępu. Tłumaczyła, że dzieje społeczne są uporządkowane przez Boga według niezmiennych praw i mają strukturę nomologiczną, dającą się odkrywać i modyfikować za pomocą rozumu i nauki, ale także strukturę, która można odnaleźć

Niektórzy podkreślają jednak, że zaplecze filozoficzne Ziemięckiej świadczy o jej nowoczesności. Zob. np. J. R. Bła c h n i o, Poglady filozoficzne Eleonory Ziemięckiej na tle sporów ideowych potowy XIX wieku. Bydgoszcz 1997. - J. M. S o s n o w s k a, wstęp w zb.: Pionierki. Krytyka artystyczna kobiet 1839-1879. Antologia. Wstęp, wybór, oprac. ... Współpr. M. Ka sa. Warszawa 2016, s. 52-55. - D. W. Maku ch, Przeciwko pozorom rozumu. Eleonora Ziemięcka i opozycje myśli nowoczesnej. „Kronos” 2018, nr 3.

E. Zi e mi ę cka: Powiastki ludowe. [Seria 1]. Warszawa 1860; Rozbiór kursów o literaturze słowiańskiej Adama Mickiewicza. W: Studia. Wilno 1860; O liryzmie. Jako uzupetnienie „Rysu piśmiennictwa naszego". W: jw., s. 102.

24 Zob. W. Po 1, list do E. Ziemięckiej, z końca lutego 1865. L 405.

25 W. Pol: list do E. Ziemięckiej, z 20 III 1864. L 389-391 (edytor błędnie przyporządkował ten list do wykładów o muzyce kościelnej, które odbyły się rok później); Pamiętnik do literatury polskiej XIX wieku. W dwudziestu prelekcjach mianych $w$ radnej sali miasta Lwowa. Lwów 1866, rozdz. 10.

W. Pol: list do E. Ziemięckiej, z przełomu listopada i grudnia 1864. L 400-401; Sześć prelekcji o muzyce kościelnej danych [...] $w$ radnej sali miasta Lwowa na sześciu wieczorach muzykalnych zarzadzonych przez Karola Mikulego [...] we Lwowie r. 1864. Lwów 1865 (w tytule najprawdopodobniej wystapił błąd - chodzi o r. 1865, a nie 1864). 
w podaniach historycznych oraz w tradycji. Człowiek jako istota „psychologiczno-moralna” też zasadniczo się nie zmienia: „równie czciciel przeszłości, jak czciciel postępu moga i powinni podawać sobie dłonie: to jest pole nieuległe sporom, na którym rozwija się filozoficzny pogląd"27.

Analizując twórczość Pola, recenzentka przekonywała, że znane z wcześniejszych dzieł kreacje Mohorta czy Wita Stwosza - gdy rozpatrywać je ze stanowiska estetycznego ufundowanego na owych prawach - nie reprezentują wartości charakterystycznych dla przeszłości, lecz są figurami „czysto ludzkimi”, przez które przeświecają niezmienne idee. Podobnie wygląda to w wypadku Pacholęcia hetmańskiego. Zdaniem recenzentki, geograficzna i historyczna lokalność świata przedstawionego w poemacie skrywa najgłębsze tajemnice wiedzy, które poeta wydobył na światło dzienne niczym naukowiec. Ziemięcka dostrzegła w dziele opis aktu boskiej kreacji, rolę wychowania, wagę domu i rodziny jako społecznych podstaw państwa. Co ciekawe, cytując obszerne wypowiedzi Pola - który twierdził, że wszystko, co wie, pochodzi z tradycji - filozofka sprowadzała jego obskuranckie deklaracje do wieszczej przesady, „szału natchnienia” i rozumiała je jako cechy swoiste stylu autorskiego, który z punktu widzenia nauki należy zignorować. W takim odczytaniu twórczość Pola nabierała walorów poznawczych, jego wskazania pedagogiczne okazywały się wartościowe nie tyle w procesie odkrywania przeszłości, ile w teraźniejszym życiu: „chciał odtworzyć to, co żywe - pod ubiegłym; co niezmienne - pod wiekowym". Jego dydaktyzm zyskiwał charakter ponadnarodowy i ponadhistoryczny. Sam Pol nie dawał żadnych „postępowych” wskazówek, jak tę uniwersalną wiedzę ukonkretnić, ale przekonujące przedstawienie prawideł powszechnych powinno zostać docenione. Plastycznie odmalowana tradycja jest bodźcem do działań, przekucie jej w postulaty współczesne to „zadania, nad którymi postęp pracować powinien" 28 .

Szkic Ziemięckiej stanowi przykład nieoczywistego w XIX-wiecznym dyskursie krytycznoliterackim spotkania się różnych, wydawać by się mogło, rozłącznych sposobów myślenia o świecie i sztuce. U filozofki przenikają się trzy tradycje: heglowski idealizm ujmujący historię i człowieka jako wcielanie się idei racjonalnej, typowo polski idealizm narodowy wyrastający z katolicyzmu i z przekonania o opatrznościowym kierunku dziejów oraz nowoczesne myślenie o historii jako o postępie cywilizacyjnym. Niezależnie jednak od światopoglądowych przygód Ziemięckiej tkwi w jej recenzji rdzeń niezwykle osobisty: zapatrzona w Pola filozofka broniła go przed oskarżeniami o naiwne hołdowanie przeszłości, bo miała świadomość, że u progu siódmej dekady XIX stulecia, zwłaszcza w kontekście oskarżeń Ujejskiego, jego przekonania można ocenić jako zupełnie nieatrakcyjne. Tym samym, neutralizując historyczne i geograficzne własności świata literackiego Pola, ratowała poetę na przekór jemu samemu.

Do szkicu autor Pacholęcia hetmańskiego bezpośrednio nawiązał w liście do Ziemięckiej z 20 III 1864, w którym dziękował za opracowanie idei filozofii niemieckiej do wykładów o literaturze polskiej. Ale zarazem Pol protestował przeciwko uznawaniu poematu o Tarnowskim i innych swoich utworów za teksty pedagogicz-

Zi e mi ę c ka, Rzut oka na nowy utwór Wincentego Pola pt. „Pacholę hetmańskie”, s. 117. 
ne. Pisał do Ziemięckiej, że całkiem niepotrzebnie zrobiła go „hardym człowiekiem w znaczeniu dzisiejszym" (L 390). Nie był to jednak wyłącznie głos obrońcy tradycji. Jak pokazują wypowiedzi samego Pola $z$ tego okresu i ustalenia badaczy, mimo niechęci pisarza do przemian cywilizacyjnych postępowość $\mathrm{w}$ jego słowniku pojęciowym zyskała z czasem wydźwięk pozytywny, a często odnosiła się do jego własnych dzieł ${ }^{29}$. Dlatego też autor tłumaczył, że choć trudno oczekiwać, by postaci historyczne wyznawały „postępowe idee dzisiejsze” ( $z$ powodu prawdopodobieństwa historycznego), to przecież sama „poezja plastyczna jest tym postępową, "że jest», że stworzyła postacie mimo mgieł zimnych i nagich idei, że je potęga prawdy poetycznej obronić zdołała w rzeczywistym świecie. Oto jest postępowa strona plastycznej poezji u nas" (L 390) ${ }^{30}$.

Wypowiedź tę pozwala lepiej zrozumieć wprowadzenie poprzedzające fragment Pacholęcia hetmańskiego w „Kółku Rodzinnym”31. Zgodnie z koncepcjami formułowanymi w romantyzmie opisano w nim kulturę narodową jako manifestowanie się czy „uobecnienie” pewnej idei. Zdaniem autora, istota polskości po raz pierwszy objawiła się za pośrednictwem kształtów, pojęć i form cywilizacji w XVI wieku. Z biegiem czasu część tych plastycznych elementów zniknęła, przekształciła się pod wpływem warunków społeczno-politycznych. Poza tym jednak wiązka form czy znamion kultury szlacheckiej przylgnęła do narodowej indywidualności i wrosła w nią jako część polskiego rdzenia. Część, która odeszła do przeszłości, może zostać ożywiona przez poetów i być doświadczana przez czytelników w twórczości, a oceniać ją należy pod względem „prawdy” historycznej. $Z$ kolei drugą część - tę, która stała się częścią polskiego kodu, a mówiąc dokładniej, niezmienną w czasie formą, w jakiej ten kod się ujawnia - również można oddać w dziele sztuki, ale trzeba ja rozpatrywać jako wierne odbicie narodowości. Niezależnie więc od czasu czy miejsca akcji utwór taki jest współczesny tylko dlatego, „że jest”, że zostały w nim przedstawione formy charakterystyczne dla narodu w ogóle - i to przedstawione tak, jakby były żywe (a skoro je ktoś podnosi, uznaje za część współczesności, to żywymi są właśnie); byłby to więc swoiście pojęty postulat realistyczny, polegający

29 Mam na myśli zwłaszcza przywoływany tu już list Pola do Keniga (z 4 VI 1860. L 361-362), swoiste credo światopoglądowe, na które składały się nie tylko przewidywalne deklaracje: „Jestem katolik”, „Jestem Polak”, ale i samookreślenia nieoczekiwane: „Jestem człowiek postępowy”, znajdujące się w otoczeniu takich zdań, jak: „Kto chce być z narodem, musi iść z wiekiem” albo „Od Hezjoda i Homera czerpała poezja tylko z przeszłości. Na tym polu pracując, dałem Narodowi rzeczy nowe, rzeczy postępowe i rozumiem, iż mam prawo jako Pisarz domagać się po dziennikarstwie rzeczy nowych i postępowych”. Zob. też A. Łuko m s ka, „Postęp musi wyrastać z przeszłości”. Wiek XIX $w$ świetle korespondencji Wincentego Pola. W zb.: Świat Wincentego Pola. Romantyzm, realizm, pamięć. Red. A. Ti m of i j jew. Lublin 2015. - O. Kry s ow s ki, Kryzys światopogladu romantycznego? Uwagi o powinnościach literatury i dziennikarstwa lat 60. XIX wieku w korespondencji Wincentego Pola. W zb.: Literatura i kultura lat 60. XIX wieku między polityka a prywatnościa. Dyslokacje. Red. U. Kowalczuk, D. W. Makuch, D. M. Os iński. Warszawa 2019.

30 Zob. też Pol, Pamiętnik do literatury polskiej XIX wieku, s. 243: „Historia, tradycja jest tym żywa, że była - ale nie tym, żeby miała zdobywać wpływ stanowczy na dzisiejsze stosunki”.

31 Nowy poemat Wincentego Pola. „Kółko Rodzinne” 1860, nr 12, z 22 V. Tekst nie jest sygnowany, co może świadczyć o tym, że pochodzi on od redakcji, ale biorąc pod uwagę kontekst innych wypowiedzi poety i pamiętając o jego bliskiej współpracy z „Kółkiem Rodzinnym”, można przypuszczać, że Pol jest autorem tego tekstu lub że przynajmniej miał czynny udziału w jego pisaniu. 
już nie tyle na wiernym oddaniu szczegółów, ile na szukaniu istoty w rozmaitych formach narodowych.

W tej refleksji - której rozwinięciem stał się Pamiętnik do literatury polskiej XIX wieku - widać inspirację estetyką Józefa Kremera ${ }^{32}$. Przywoływany w omówionym artykule myśliciel uważał, w duchu polskiej szkoły idealistycznej, że sztuka polega na ubieraniu treści idei w formę plastyczną, tym ważniejszą, iż władza fantazji, odpowiedzialna za proces kształtowania, miała być właściwością najmocniej rozwiniętą wśród narodów słowiańskich ${ }^{33}$. Pol za jedyną ideę warta opracowywania uznawał w tym wypadku polskość, która najpierw ujawniała się w postaci rozmaitych fenomenów kultury narodowej, a następnie została ukształtowana w dziele sztuki, w taki sposób, by odbiorca mógł ją dostrzec i pojąć, ponieważ idea sama w sobie, jako abstrakcja, pozostawała nieprzenikniona, „Zimna i naga”.

Jak widać, i Ziemięcka, i Pol posługiwali się opozycją istoty i fenomenu, treści i formy, ale uniwersalności przypisywali dwa różne znaczenia: filozofka - ogólnoludzkie, poeta - narodowe. Ona na podstawie idei ogólnych wolała formułować postulaty praktyczne, bliska była więc utylitarnemu traktowaniu sztuki; jemu wystarczał opis Polaków jako wspólnoty, w kontrze do dziennikarskiej „bieżączki”, która w służbie kapitału rozbija obywateli na stronnictwa ${ }^{34}$, czy do politycznych powieści tendencyjnych pisanych dla praktycznych korzyści jakiejś grupy ${ }^{35}$. Poemat Pacholę hetmańskie, ze swoimi rozbudowanymi opisami kształtów życia szlacheckiego, miał więc nie tylko cieszyć plastycznymi obrazami przeszłości, lecz także poszukiwać form cywilizacyjnych, które wrosły w narodową indywidualność, stanowić odbicie głębokiej, idealnej tożsamości zbiorowej. Mniejsza o to, które z nich uznałby Pol za ważne, bo - jak zawsze w przypadku teorii idealistycznych - wybór wartości był cokolwiek arbitralny ${ }^{36}$. Większe znaczenie zdaje się mieć rosnące zainteresowanie dojrzałego pisarza sprawami niezmiennymi, które szło w parze $z$ nasilającą się niechęcią do twórczości literackiej jako poruszającej się po stronie form,

Przypomnienie prac o działalności historycznoliterackiej Pola oraz jej nową interpretację przedstawiła ostatnio U. Kowalczuk (Wincentego Pola „Pamiętnik do literatury polskiej XIX wieku”. Geografia między historia literatury a autobiografia. W zb.: Literatura i kultura lat 60. XIX wieku między polityka a prywatnościa). O wpływie Kremera zob. M. Ło b o z: op. cit., rozdz. „Mówicie, że ja nie jestem artystą?” - estetyczne inspiracje Wincentego Pola; „Krajowidoki” Wincentego Pola $w$ kręgu estetyki romantycznej (inspiracje Józefa Kremera). W zb: Obrazy natury i kultura.

Zob. D. W. M a ku c h, Wokót pojęcia fantazji. Południe XIX wieku i przemiany idealizmu. Warszawa 2018, s. 35-77.

34 To nawiązanie do listu programowego W. P o la do „Kółka Rodzinnego” z początku r. 1860, a przedrukowanego ostatecznie w Stryjance (Warszawa 1860), pt. Stów kilka nie należacych do objaśnień „Stryjanki”, który w wiadomości do Keniga poeta opisuje dodatkowo jako „ale do czasu, w którym ta książka wychodzi” (L 362). Wydaje się więc, że Pol odnosi się do oskarżeń Ujejskiego (może post factum?), nawet jeśli zdaniem edytora list powstaje jeszcze przed nimi (choć pewności mieć nie można).

Zob. Po l, Pamiętnik do literatury polskiej XIX wieku, s. 300.

Można sądzić, że Polowi chodziło w tym wypadku o określony typ wychowania, przywiązanie do wiary katolickiej, podtrzymywanie więzów unii lubelskiej, a przede wszystkim o pewną strategię upamiętniania i żałoby, co analizuję w części trzeciej artykułu. Listę ideałów szlacheckich opisanych w poemacie przedstawiła także Bryła (op. cit., s. 137-181). 
a nie istoty: „Plastyczne kształty nawet chrześcijańskich postaci znużyły mnie, nie chcę, nie mogę być dłużej rzeźbiarzem, uciekam się więc do sfery tonów"37.

Dzieła $z$ tego okresu pokazują, że piewca lokalności i szczegółu szukał śladu większej całości: wzoru ukrytego pod mnogością zjawisk. Zacytowane zdanie pochodzi z listu zapowiadającego wykłady o muzyce kościelnej, która jako najidealniejsza ze sztuk ${ }^{38}$ najłatwiej komunikowała niezmienne wartości. W swoich prelekcjach na ten temat Pol nie zajmował się sprawami formalnymi czy historycznymi, ale porządkował muzykę według ezoterycznych tonów, którym nadawał znaczenie w kontekście religii w ogóle. Opowieść o muzyce stawała się historią stosunku człowieka do Boga, konkret znikał więc w odniesieniach do spraw ostatecznych. Podobne transcendowanie ku ideom „uobecnionym” w świecie widać w pracach, do których tworzenia Pol wrócił u progu lat sześćdziesiątych XIX stulecia. W Geografii Ziemi Świętej detale topograficzne liczą się pod warunkiem, że opisane są w Biblii ${ }^{39}, \mathrm{z}$ kolei w Roku myśliwca przyrodnicza mnogość została zamknięta w mitycznym czasie cyklicznym, w wiecznej powtarzalności sekwencji miesięcy i pór roku. Nawet Pamiętnik do literatury polskiej XIX wieku to nie tyle opis poszczególnych dzieł, ile przemyślana, całościowa i dialektyczna wizja procesu historycznoliterackiego, w której najważniejsze są idee i ich wpływ na świadomość narodu.

\section{Niedoczytanie drugie - epika i epos}

Wróćmy do odpowiedzi danej Ziemięckiej. Pol nie rozumiał, dlaczego „szanowna autorka” zestawiła Pacholę hetmańskie z Mohortem czy Witem Stwoszem, miał bowiem nieskromne poczucie, że jego nowy utwór jest na wskroś oryginalny:

Co do Pacholęcia hetmańskiego, było Pacholę hetmańskie, a raczej Diariusz jego, tylko szukaniem nowej epickiej formy, odpowiednim tradycjom naszym, i znać, iż tu rywalizacja $z$ ideałem nie pomogła, kiedy Pani tego nie widzisz, pedagoga tu upatrujesz, gdzie poeta sądzi być e pikiem. Znać tedy, że główne założenie nie osiagnięte, chociaż mam to przekonanie, że moja o d y s e a znacznie jest odmienna od wszystkich poprzednich, i to nie tylko w literaturze naszej, ale w literaturze europejskiej. Żałuję bardzo tego, że Goethe nie żyje, on także szukał form e pickich, bobym sam dla niego przetłomaczył Pacholę hetmańskie [...]. [L 390; podkreśl. D. W. M.] $]^{40}$

Sądzę, że odyseję Walentego Rożanki należałoby określić mianem nowoczesnej, autorskiej wersji epopei ${ }^{41}$, przy czym epopeję rozumiem tu jako pojęcie genologiczne i historiozoficzne, odnoszące się do całokształtu myślenia o dziejach na-

Po 1, list do Ziemięckiej, z przełomu listopada i grudnia 1864. L 400.

Bo najmniej skażona materialną formą - to oczywiście nawiązanie do wykładni G. W. F. He gla (Wykłady o estetyce. Przeł. J. Grabowski, A. Landman. Objaśn. A. Landman. T. 2. Warszawa 1966, s. 318 n.), dominującej w romantyzmie - zob. A. Ein stein, Muzyka w epoce romantyzmu. Przeł. M. i S. J a r o c iń s c y. Wyd. 2. Warszawa 1983.

W. Po 1, Geografia Ziemi Świętej. Lwów 1863. Na ten temat: A. J a ck ow s ki, Wincenty Pol-prekursor geografii religii $w$ Polsce. W zb.: Obrazy natury i kultura.

Zob. też W. Pol, list do L. Pietrusińskiego, z kwietnia 1861. L 375-376 (podkreśl. D. W. M.): „[Pachole hetmańskie] Jest to mozaika historycznych postaci, narodowych tradycji i religijnych, w formie szlacheckiego diariusza, w istocie zaś natury e pi c ki j””.

Co ciekawe, wersja ta nie wpisuje się w żaden z typów romantycznego eposu wymienionych przez M. Sokołowskiego (Epopeja. Hasło w: Stownik polskiej krytyki literackiej 1764-1918. Pojęcia-terminy - zjawiska-przekroje. T. 1. Red. J. Bachórz, G. Borkowska, T. Ko stki e- 
rodu ${ }^{42}$. To z nią trzeba powiazać Goethego, ale i Homera, Hezjoda czy Dantego - twórców, których dzieła w czasie pisania Pacholęcia hetmańskiego uznawał autor za źródło poezji plastycznej ${ }^{43}$, punkt wyjścia dla tradycji literackiej; $z$ nią też łączył Pana Tadeusza, czyli „największy narodowy poemat, jaki mamy w narodzie”44. Na epopeję wskazywałoby zakończenie wiersza Salve Regina z tomu Kilka kart z krwawego rocznika, upamiętniającego wydarzenia powstania styczniowego. Wiersz jest zapisem snu, w którym podmiot widzi, jak śmiertelnie rannego w głowę powstańca, Juliusza Tarnowskiego, brata przyszłego stańczyka, podejmuje w niebiosach sam wielki hetman, bohater Pacholęcia [...], wraz z zastępem uznanych sandomierzan. W tym kluczowym dla dziejów epickim momencie historia miesza się ze współczesnością, nakłada się na nią, ukazuje swój porządek i zasadniczą jedność. Całą wizję śniący puentuje następująco:

\footnotetext{
Jakże się dziwnie plotą one dzieje

Stare z nowymi - bez końca, początku,

$Z$ jednego ducha, i $z$ jednego wątku

Widzę i czytam: wszędzie epopeje! ${ }^{45}$
}

O skłonności Pola ku konkretnemu modelowi poezji epickiej świadczą refleksje zawarte w wykładach o literaturze, pochodzacych $z$ tego samego okresu co list do Ziemięckiej. Pol uważał się za nowatora, ponieważ stworzył dzieło na miarę swoich czasów i syntetyzował w poemacie cechy charakterystyczne dla ostatniego etapu przemian procesu historycznoliterackiego rozumianego jako proces teleologiczny, który to proces Pol umiał uchwycić w jego całości dzięki „dialektycznej wprawie” (L 389) $^{46}$. Jak twierdził, polskie pisarstwo XIX stulecia jest epopeją, jego istotę stanowi epopeiczność, ponieważ „tu występuje na widownię dziejów bohaterstwo ducha, potęga miłości, siła i dzielność, która sama sobą stoi i tylko albo w miłości Boga, albo w miłości ojczyzny czerpie swoje siły!" 47 . Niezorientowany czytelnik będzie widział w tym stwierdzeniu jedynie garść frazesów, krytyk idealistyczny w każdym $z$ określeń odnajdzie jednak odwołanie do konkretnych koncepcji i do związanych $z$ nimi kategorii, w tym wypadku zapożyczonych głównie od Józefa Gołuchowskiego $^{48}$. Najważniejszą $z$ owych kategorii jest kategoria miłości, dzięki

wiczowa, M. Rudkowska, M. Strzyżewski. Toruń-Warszawa 2016, s. 340-345. Warto dodać, że każdy z tych typów ma swoje źródło w tradycji niemieckiej.

Jest to rozumienie charakterystyczne dla epoki - zob. M. P i e c h o ta, Epopeja (epos, poemat heroiczny). Hasło w: Słownik literatury polskiej XIX wieku. Red. J. B a c hó r z, A. Ko w a lc z y k o w a. Wyd. 4, bez zm. Wrocław 2009, s. 239.

Pol, list do Ziemięckiej, z 20 III 1864. L 390. Zob. też przypis 29.

P o1, Pamiętnik do literatury polskiej XIX wieku, s. 381.

[W. P o l], Salve Regina. W: Kilka kart z krwawego rocznika. Lipsk 1864, s. 26.

46 Więcej na ten temat zob. M. St a n is z, Drogi rozwojowe dziewiętnastowiecznej literatury polskiej wedtug Wincentego Pola. W: Obrazy natury i kultura.

47 P o 1, Pamiętnik do literatury polskiej XIX wieku, s. 8. Zob. też ibidem (podkreśl. D. W. M.): „I nie jest to zaprawdę figura poetyczna, jeżeli literaturę polską XIX wieku porównywam do e p o p ei; owszem, jest to najwymowniejsza rzeczywistość i najwłaściwsze może jej określenie. Literatura polska XIX wieku jest bowiem najnowszą tradycją narodu. [...] Tradycja zaś, do której odwołać się można - to prawdziwie e pi cki żywioł [...]”.

48 J. G oł u c how s ki, Dumania nad najwyższymi zagadnieniami człowieka, poprzedzone historycznym rozwinięciem głównych systemów filozoficznych od Kanta do najnowszych czasów. Wilno 1861. 
której człowiek może przekroczyć czasoprzestrzenną ograniczoność i niewiedzę charakterystyczną dla kantowskiego podmiotu i która pozwala na uporządkowanie świata. $Z$ tej najwyższej kategorii trzeba wywieść „cały plan boży, całe dzieje stworzenia i odkupienia człowieka" 49 .

Nic dziwnego, że Pol był niezadowolony, gdy Ziemięcka nazywała go pedagogiem. Nie uważał się wówczas za pisarza zaangażowanego - to określenie nie oddawało jego ambicji. Lirnik, poeta, śpiewak zapragnał sławy wielkiego epika, chciał jako wyraz narodowego ducha przedstawić w obrazach przeszłości „najnowsze tradycje narodu" - tradycje, warto dodać, wciąż żywe. Epickość, historyczność i tradycjonalizm splatały się więc ze sobą, a ich syntezą był obraz unii lubelskiej czy wychowania hetmańskiego, uznanych za konstytutywne składniki kodu polskości. Trzeba jednak pamiętać, że w Pacholęciu hetmańskim Pol opisywał to, co z perspektywy lat sześćdziesiątych XIX w. wydawało mu się najbardziej swojskie i co pretendowało do idealnego porządku ugruntowanego na Biblii. W poemacie na płaszczyźnie temporalnej ukazywał to motyw rzymskiego zegara, mikrokosmosu odbijającego porządek świętego czasu religijnego ${ }^{50}$, a na płaszczyźnie przestrzennej - podróż do Ziemi Świętej, chrześcijańskiego axis mundi, do którego pielgrzymuje Rożanka po smierci hetmana.

Pol byłby więc - według trafnej, znacznie późniejszej metafory Cezarego Jellenty - „zakapturzonym idealista”, bo w nowej epickiej formie za pośrednictwem lokalnego i historycznego szczegółu szukał trwałego i niezmiennego porządku świata ${ }^{51}$. W ten sposób antycypował wielkie powieści historyczne i panoramiczne powieści realistyczne $z$ lat osiemdziesiątych XIX stulecia, których czasoprzestrzenna głębię próbowała ująć dopiero pozytywistyczna krytyka literacka ${ }^{52}$.

Nie trzeba jednak sięgać po przykłady tak odległe czasowo, by zrozumieć nośność pojęcia epopeiczności u Pola. Dość przypomnieć, że po upadku powstania listopadowego nasiliło się „romantyczne marzenie o epopei” ${ }^{3}$, co sprawiło, że elementy tego gatunku zaczęły przenikać do poezji i do coraz bardziej epicznego dra-

Książka ta była wydana i promowana przez E. Zi e mi ę c ką, która zresztą napisała do niej wstęp (Wspomnienie o Józefie Gołuchowskim), a w swoich Studiach zamieściła jej analizę („Dumania nad najważniejszymi zagadnieniami dla Człowieka” [!], dzieło Józefa Gołuchowskiego). P o 1 (Pamiętnik do literatury polskiej XIX wieku, s. 226) mówi o owym dziele w wykładzie, który pomogła mu przygotować Ziemięcka: „Od tego [...] czasu [tj. od momentu, gdy Gołuchowski ogłosił swoją teorię] mogliśmy powiedzieć właściwie nie to, żeby nasz naród utworzył nowy systemat filozoficzny, ale że wszystkie kwestie najwyżej obchodzące człowieka, naród i ludzkość, wszystkie kwestie zaświatowe są najlepiej w tym dziele rozwiązane". o 1, Pamiętnik do literatury polskiej XIX wieku, s. 225.

Motyw ten został już dobrze opisany jako jeden z najbardziej rozpoznawalnych i wartościowych fragmentów poematu. Zob. Łob oz, Śpiewak pieśni niedogranych, s. 114-118. - B ryła, op. cit., s. $152-154$.

C. J elle n t a, Zakapturzony idealizm. „Prawda” 1888, nr 35, z 1 IX (20 VIII).

Zob. np. E. Pa czo s ka, Krytyka literacka pozytywistów. Wrocław 1988, s. 60-94. - T. Sobi er aj, O naukowe podstawy twórczości i krytyki literackiej. Bolesława Prusa recenzja „Ogniem i mieczem”, studium o „Farysie” $i$ „S Słówko o krytyce pozytywnej”. W zb.: Bolesław Prus. Pisarz nowoczesny. Red. J. A. Malik. Lublin 2009.

To tytuł rozdziału pracy K. Try bu s i a Epopeja w twórczości Cypriana Norwida (Wrocław 1993), zawierającego syntetyczne podsumowanie rozmaitych związków między twórczością pisarzy romantycznych a wzorcami epopeicznymi. 
matu, ale też do gawędy czy powieści. Rozszerzenie się ram genologicznych eposu i zmiany w rozumieniu pojęcia wynikały z tęsknoty za formą literacką, która zobrazowałaby duchowe przesilenie Polaków, a zarazem mogłaby stać się czymś w rodzaju narodowej syntezy dziejów przychodzącej w dobie kryzysu. Stąd też najwięksi pisarze epoki w swoich wypowiedziach chętnie posługiwali się „eposem” jako kategorią nobilitująca, nawet jeśli - jak w przypadku Norwida - uznawali, że trudno ją w pełni zrealizować w świecie nowoczesnym. Według Norwida epopeja wymagała unowocześnienia, dostosowania do wyzwań cywilizacji, krytycznego rozliczenia się $\mathrm{z}$ całą gamą typów gatunkowych i zmierzenia się $\mathrm{z}$ wielkimi dziełami poprzedników ${ }^{54}$. Zastrzeżenia te Norwid bezpośrednio wyraził w Quidamie: prezentując odmienna koncepcję bohatera i odrębne przekonania historiozoficzne dokonał on weryfikacji romantycznych marzeń o epopei. Niezależnie jednak od ocen i realizacji poeta w swoich prelekcjach dawanych w Czytelni Polskiej w 1860 r. (a więc niemal w tym samym czasie, kiedy Pol formułował swoje rozważania historycznoliterackie) określał literaturę epopeiczna jako „całość dokonań poetów; czyn i słowo zarazem”, „poezję zmieniająca historię świata i stającą się historią" 55 . Przy całej swej osobności głosił więc to samo co Mickiewicz czy Krasiński - epopeiczną literaturę utożsamiał z czynem narodowym, przy czym miał na względzie charakterystyczną dla epoki wieloznaczność i rangę tego pojęcia.

Najlepszą egzemplifikacją tendencji rozszerzających semantyke pojęcia epopei okazał się proces recepcji Pana Tadeusza, który - zdaniem Kazimierza Wyki - odegrał kluczową rolę w „stawaniu się epopei”, wbrew początkowej intencji autora i na przekór starożytnym poetykom ${ }^{56}$. Badania nad kształtem i odbiorem Mickiewiczowskiego arcydzieła uzmysławiają dodatkowo, jak wiele gatunków, stylów i typów narracji pozostawało $\mathrm{w}$ epoce $\mathrm{w}$ polu epopeiczności, jak odmiennie podchodzili do klasycznego Homerowskiego wzorca romantycy, na ogół traktujący przecież bardzo swobodnie wszelkie poetyki normatywne ${ }^{57}$. Dopiero uwzględnienie tej heterogenicznej i wieloaspektowej natury pojęcia epopei pozwala na zrozumienie cech charakterystycznych Pacholęcia hetmańskiego, w tym kontekście zamysł Pola zyskuje na klarowności.

Nie sposób prześledzić tu wszystkich cech pojemnego znaczeniowo, nowoczesnego eposu, które odcisnęły piętno na omawianym dziele. $Z$ innych wypowiedzi Pola można wywnioskować, że Pacholę hetmańskie należy sytuować w kręgu kategorii zaczerpniętych z filozofii niemieckiej, przez których pryzmat Pol postrzegał swoja twórczość. Dla Goethego, Jeana Paula, Hegla czy Friedricha Theodora Vischera epopeja była bowiem emanacją i opisem ducha narodu w epickim dziele literackim. Hugo Zathey w odniesieniu do Pana Tadeusza referował te przekonania estetyczne w następujący sposób:

Epos okazuje nam naród w całej życia zupełności, istocie i treści. Zamyka on w sobie rdzeń i ducha

Przypomnijmy, że jest on autorem typologii epopei chrześcijańskiej. Zob. C. No r w i d, O Juliuszu Słowackim w sześciu publicznych posiedzeniach. W: Proza. Cz. 1. Oprac. J. W. Gomulicki. Warszawa 1971, s. 454. Pisma wszystkie. T. 6. 
jego. Obejmuje bardzo rozległy zakres - nie pomija nic, [...] a zastanawia się starannie, z cierpliwym spokojem i pewnym naiwnym zadowoleniem nad stosunkami umysłowego, religijnego i domowego życia; przedstawia naród w pokoju i wojnie, w radzie i w kościele, na roli i w zaciszu domowym, [...] daje nam całokształt pojęć, wyobrażeń, uczuć i myśli ${ }^{58}$.

W tej wielości epizodów pojawia się jednak bohater epicki, który scala wszystkie historie.

Bohater epiczny nie działa [...] dramatycznie, nie walczy z losem jak bohater tragiczny, lecz ulega w wielu rzeczach losowi jako też powszechnemu porządkowi rzeczy, który i w epopei ma swoje ustalone miejsce i powage ${ }^{59}$.

Epickość to żywioł prawdy. Epik winien troszczyć się o wierne odmalowanie każdego szczegółu, bo w ich sumie ukryta jest duchowa istota danego narodu.

Spojrzenie na Pachole hetmańskie jak na nowoczesną epopeję inspirowana niemieckimi teoriami pozwala zrozumieć dotąd krytykowane cechy tekstu - jego epizodyczność, niezborność, brak wyraźnej linii fabularnej, bierność postaci hetmana i Walentego Rożanki, zasadnicze pogodzenie się ze światem, dygresyjność przechodząca w ekstensywne opisy obyczajowości polskiej szlachty, namnożenie postaci mało ważnych $z$ punktu widzenia przekazu ideowego. Potwierdzenie tej tezy można znaleźć we fragmentach, które ostatecznie do utworu nie weszły - takich jak bliski klasycznej inwokacji Przedsionek. Podobnie tematyzowana w tekście siła opatrzności i cały wymiar religijny stawałyby się w tym oświetleniu tylko inną odmianą epopeicznej cudowności.

Słusznie przewidywał jednak poeta, że forma ta nie zostanie rozpoznana ani zrozumiana. Oto co pisał Lucjan Siemieński o tym nowoczesnym eposie:

Widocznie [Pol] nie chciał [...] nic mieć wspólnego ani z formą starożytnej epopei, ani z nowożytnym powieściowym poematem byrońskim. Dążność ta antyliteracka nadała pewną ociężałość jego płodom; akcja, łamana ciąłymi epizodami, nie porywa za sobą czytelnika ani uwagi jego nie trzyma w natężeniu ${ }^{60}$.

Krakowski krytyk za gatunkowe odkrycie Pola uważał gawędę. Według Siemieńskiego była ona ,jakby wypoczynkiem dla epika, który pokazawszy swego bohatera w samej akcji, chce go jeszcze dać poznać i z tych czynów, jakie nie weszly w zakres epopei, i każe mu opowiadać"61.

Właśnie diariuszowość Pacholęcia hetmańskiego przeszkadzała Siemieńskiemu w „poprawnej” klasyfikacji, bo - jak się zdaje - zbyt mocno osadzała utwór w mikrohistorii, w pojedynczej biografii szlacheckiej. Pol natomiast mógł upatrywać w tym rozwiązaniu największą zaletę utworu. W końcu w swoich wykładach głosił, „że się dziś era powieści skończyła i że się zaczyna era pamiętników”62. Osobistość i prywatność zapisków jednostki paradoksalnie bliższa była sferze ogólnoludzkich czy ogólnonarodowych wartości niż rozpolitykowana powieść tendencyjna, ponieważ

61 Ibidem, s. 39-40.

62 Po l, Pamiętnik do literatury polskiej XIX wieku, s. 294. s. 48 .
H. Za th ey, Uwagi nad „Panem Tadeuszem”. Poznań 1872, s. 18.

Ibidem, s. 20. Dobitnie jakość tę opisał A. M i c k i e w i c z, który - jak udowadnia Wyka - w swoich rozważaniach nad eposem bliski jest myślicielom niemieckim: „Epopeja zawsze kończy się tam, gdzie zaczynają się nieszczęścia bohaterów” (cyt. za: Wy ka, op. cit., s. 195).

L. Siemieński, Wincenty Pol i jego poetyczne utwory. Liryki, gawędy, dramat. Kraków 1873, 
„W pamiętnikach człowiek sam zostawiony sobie i w walce $\mathrm{z}$ życiem musi koniecznie powrócić do wszystkich ideałów, które mu w walce $z$ życiem siły dodają 63 .

Wybór Rożanki jako narratora, a diariusza jako formy opowiadania stanowił dla Pola kompensację tego, czego najbardziej brakowało mu we współczesnych powieściach czy gawędach politycznych - chodziło o znalezienie uniwersalnego klucza do świata i etycznego wzoru skrytego pod mnogością detali jawiących się jednostce. Drobiazgowy opis wychowania pacholęcia na dworze hetmana i jego późniejszych przygód pokazuje, że wartości przyswojone w dzieciństwie staja się dla bohatera kompasem moralnym, który pozwala mu orientować się w przyśpieszającym świecie. Ten niezmienny zbiór zasad Pol chciał odnajdywać również wśród współczesnych.

Wiedząc o pamiętnikarskim wymiarze nowoczesnej epiki, o diariuszowości polskiej epopei, trzeba spojrzeć inaczej na szczególnie osobiste, liryczne i okazjonalne poezje Pola $z$ tego okresu, reprezentowane np. przez Kilka kart z krwawego rocznika czy Pieśń o domu naszym. Ich prywatny wymiar nie oznaczał zamknięcia się poety przed światem, ale - przeciwnie - jego codzienne mierzenie się $z$ wartościami uniwersalnymi. Życie powszednie, $z$ domowymi obowiązkami i wiejskimi przyjemnościami - trochę jak we wcześniejszym opracowaniu liryzmu Ziemięckiej $^{64}$ - ukazuje swój sens nie tylko w odniesieniu do jednostki. Nawiązując do formułowanych ostatnio tez o biedermeieryzmie Pola ${ }^{65}$, można skonstatować, że ow biedermeieryzm jest przede wszystkim efektem konsekwentnego poszukiwania wartości w tym, co oswojone, przeciętne, ale też zakorzenione w chwili.

Wiadomo, że pod koniec lat pięćdziesiątych XIX stulecia Pol prowadził zapiski osobiste i zajął się pracami edytorskimi, które zaowocowały wydaniem diariusza Z wyprawy wiedeńskiej66. Nie przypadkiem swoją summę historycznoliteracka określił jako „pamiętnik”; jak wskazuje Urszula Kowalczuk, w dobie rewaloryzowania własnej twórczości autor stworzył syntezę historiograficzną z „wszyfrowaną niestandardową autobiografią" 67.

Poszukiwania Pola znów nie były odosobnione. Oto np. Norwid umieścił w Vade-mecum wiersz Dziennik i epos. Obie tytułowe „formy” uznał tam za niezmiennie jaśniejące ponad falą czasów - wbrew swojej niechęci do prasy wierzył więc w możliwość istnienia gazety codziennej, która dotykałaby żywiołu historii w podobny sposób co tłumaczona przezeń Odyseja. Niemniej najbliższym poprzednikiem $\mathrm{Pa}$ cholęcia hetmańskiego pozostaje Pan Tadeusz jako arcydzieło biedermeierowskiego eposu idyllicznego, w ujęciu zaproponowanym przez Dobrochnę Ratajczakową, która właśnie za Vischerem rekonstruowała nie-romantyczną ramę ideową poematu, wskazując, że trudno wyjaśnić jego swoistość w obrębie jednego prądu ${ }^{68}$. Naj-

Ibidem, s. 304.

Zi e mi ę c ka, O liryzmie, s. 101.

Zob. M. Ma ka r u k, W stronę biedermeieru. W zb.: Świat Wincentego Pola. - M. Ło b o z, Tradycja $i$ detale. Biedermeieryzm Wincentego Pola. W zb.: Obrazy natury i kultura.

Zob. W. Po 1, Pamiętniki. Oprac. K. Lew i cki. Kraków 1960. - M. Dy a kow s ki, Diariusz wiedeńskiej okazji r. 1683. Opisat pokojowiec króla Jana III. W: W. Pol, Z wyprawy wiedeńskiej. Rapsod rycerski. Lwów 1865.

Kow a lc zu k, op. cit., s. 358.

D. Rataj c za kow a, Arcydzieło biedermeieru? W zb.: Codzienność w literaturze XIX (i XX) wieku. Od Adalberta Stiftera do wspótczesności. Red. G. B or k ow s ka, A. M a z u r. Opole 2007. 
bliższym, ale przecież nie tożsamym - o czym świadczą nie do końca sielankowy charakter dzieła Pola i jego stosunek do przeszłości, której na pewno nie sprowadziłby on do dystansującej frazy „ostatni zajazd”.

Zanim jednak o różnicach, warto zamknąć wątek fiaska interpretacyjnego Ziemięckiej. I ona, i Pol odwoływali się do podobnych tradycji myślowych, a przecież rozminęli się w ocenach i oczekiwaniach. Okazuje się, że eklektyczne nurty polskiego idealizmu - chociaż wypływały z tego samego, niemieckiego źródła i zasilane były tą samą myślą katolicką - płynęły odrębnymi korytami i nie prowadziły do jednakowych rozlewisk, miały sobie właściwe przełomy, ujęcia i ujścia, dlatego warto badać je nie z perspektywy systemu, ale - indywidualnej drogi twórczej.

\section{Niedoczytanie trzecie - grób i żałoba}

4 II 1861 w Przemyślu Pol stworzył interesujący literacki komentarz literacki. Wiersz Piszac poemat „Pachole hetmańskie” - bo o nim tu mowa - przez swój osobisty charakter jasno wskazuje, że tytułowego poematu nie należy uważać za gawędę z przeszłości. Utwór ten, rozpoczynający się (znaną) eksklamacją „Smutno mi, Boże! - smutno nad ta praca”, wyraża rozgoryczenie i żal, że oto „nożem złości” naród kraje serce swojego wiernego sługi ${ }^{69}$. Jedyną kryjówka przed zniewagami wydaje się grób, potraktowany - paradoksalnie - jako miejsce nowego życia. W tej przestrzeni „praca duchów” z przeszłości powoli „spłaca boleścią wielkie gminu długi”, pojawia się perspektywa ofiary i wskrzeszenia, lecz okupiona jest ona wysiłkiem, wymaga zaparcia się starego życia i wejścia w jakieś życie nowe, to zapośredniczone przez grób, odnowione w prawdzie przeszłości:

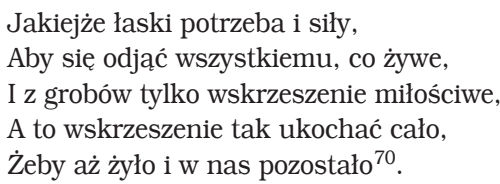

Motyw ten wielokrotnie powraca w późnych tekstach Pola. Np. w Pieśni o domu naszym tajemniczej prawdy znowu trzeba szukać w niedostępnej głębi: ukryto ją na „dnie życia”, podmiot apeluje więc o to, by zstąpić do mogiły i zbliżyć się w ten sposób do niepodważalnej wiedzy („W głębi prawda niby w grobie”, „Winy trzeba szukać w sobie - / Prawdy w Wierze - życia w grobie" ${ }^{71}$ ). Co ciekawe jednak, w obu utworach ten aspekt poznawczy łączy się z godnym przeżywaniem żałoby. W Pieśni o domu naszym żałoba ma wymiar ponadindywidualny:

\footnotetext{
Na dno życia! - kto chce $z$ Bogiem

Przetrwać wiernie czas żałoby.

Grób - wieczności świętym progiem ${ }^{72}$.
}

W. Pol, Pisząc poemat „Pacholę hetmańskie”. W: Poezje. T. 5. Lwów 1878, s. 450-451. Dzieła wszystkie wierszem i proza. T. 9. Wiersz został opublikowany w wydaniu pośmiertnym, ale - jak głosi strona tytułowa - ,przejrz[anym] i uporządkowanym przez samego autora”. Ibidem, s. 450.

W. P ol, Pieśń o domu naszym. Lwów 1866, s. 16, 19.

Ibidem, s. 17. 
Tymczasem w wierszu Piszac poemat „Pacholę hetmańskie” ukazany jest jej osobisty wymiar:

\author{
Między grobami są dla mnie dwa groby \\ Wielkiej miłości i wiecznej żałoby: \\ A więc za siebie przy nich ja dziś płacze \\ Na żywot w bólu i prace tułacze \\ I pytam Boga w tej duchów zamieci: \\ Stojąc jak stałem, gdzie będzie grób trzeci? ${ }^{73}$
}

Podobnie minorowy ton powracał też w korespondencji Pola, zwykle właśnie przy okazji wzmianek o Pacholęciu hetmańskim. Oto jak żalił się poeta, tłumacząc, dlaczego rękopis poematu spoczywa jeszcze u ks. Scipiona del Campo:

Wypada podsumować mozolny żywot - obliczyć się z odbytej drogi z sobą, z Bogiem - ja nie mam czego szukać w świecie, a jeżeli Narodowi jeszcze czym służyć mogę, to tylko pracą w tym zaciszu na starym pograniczu, na kresach ducha! Ta była ostatnia rada Kornelii, teraz dopiero mogę dopełnić jej woli $^{74}$

Po odzyskaniu rękopisu poeta zasadniczo nie zmienił postawy:

odczytuję Pacholę hetmańskie jak rzecz zupełnie nową i obcą dla mnie, nie wiem, czy ja już co z tego zrobić potrafię? Nieszczęśliwe to prace, które śmierć drogiej nam osoby przerywa! Od śmierci Kornelii nic dobrego zrobić nie umiem ${ }^{75}$.

Jeśli wziąć pod uwagę przytoczone wypowiedzi, można potraktować Pacholę hetmańskie jako tekstualizację swoistego procesu żałoby. I nie chodzi mi o naiwne poddawanie Pola psychoanalizie, choć przecież idea poematu zrodziła się zaraz po śmierci bliskich. Mam na myśli proces dalece ogólniejszy i bardziej wieloznaczny, związany z trudną sytuacją życiowa artysty, geografa i człowieka, która przekłada się na pewna postawę wobec świata ${ }^{76}$. Chodziłoby więc o patrzenie na rzeczywistość z perspektywy żałobnika, który czuje, że z żyjącymi ma coraz mniej wspólnego, który zamyka się we własnym wnętrzu i który jeśli już szuka wyjaśnień i wykonuje pracę żałoby, to nie po to, żeby wrócić do świata żywych, ale żeby przygotować się na połączenie $z$ utraconym obiektem w tajemniczej, duchowej przestrzeni.

Losy Walentego Rożanki skupiają się wokół żałoby i żałobników, co widać już na poziomie leksykalnym - słowo to powraca $z$ dużą frekwencją. Najmocniej jednak o żałobnym charakterze dzieła świadczy fabuła. Bohatera poznajemy jako dziecko, którego ojciec po śmierci żony (będącej matką diarysty) stracił rozsądek i popadł w rozpacz, w związku z czym Walenty został oddany pod opiekę hetmana. Księga druga rozpoczyna się od opłakiwania śmierci króla Zygmunta Starego, a w całości lę hetmańskie w kategoriach dzieła żałobnego, a nie elegijnego. Dla tej drugiej kategorii, nawet jeśli w XIX w. wykraczała ona poza estetykę, kluczowe pozostawały temat i nastrojowość dzieła. Model świadomości elegijnej zrekonstruowany przez P. Ś n i e d zi e w s k i e go (Elegïna świadomość romantyków. Gdańsk 2015) nie przystaje do rozważań Pola ani w wymiarze emocjonalnym podmiotu elegijnego (odczuwanie straty, wyobcowania, „przyjemnego smutku” $i$ „słodkiej melancholii”), ani w wymiarze uruchamianych przezeń strategii obronnych (poczucie niezmiennej tożsamości). 
poświęcona jest umieraniu Tarnowskiego. Kończy się ona dramatem kolejnej osoby nie pogodzonej ze strata - ukraińskiego sokolnika Maruszki ${ }^{77}$. Księga trzecia opisuje żałobę po hetmanie, czas, kiedy „cała Polska była na pogrzebie”78, a koncentruje się na wdowie hetmanowej, która nie przestaje opowiadać o zmarłym mężu. Ale jeszcze $\mathrm{w}$ tej samej księdze i ona umiera, wraz z nią odchodzi jej syn, pan Wojnicki, po czym ze światem żegnają się ojciec Rożanki i ksiądz Melchior, jego wychowawca. W ramach żałoby diarysta rusza do Ziemi Świętej, gdzie czeka na zjednoczenie $z$ duchami przeszłości. Księga czwarta traktuje o porwaniu Rożanki, przy czym skupia się na postaci Stacha Nałęcza, cudownie ocalałego chłopca, który większość wysiłków poświęci właściwemu uhonorowaniu zmarłego ojca. Księga piąta, w której Rożanka po latach wraca na ojcowiznę, znów rozpoczyna się od opłakiwania zmarłych piastunów, upamiętniania hetmana i przygotowywania na własną śmierć. Dopiero w swoistym epilogu, napisanym pod koniec życia przez tytułowego bohatera, poznajemy największe sukcesy militarne Tarnowskiego. Istnieją więc one niejako poza samym poematem, są wynikiem pracy żałoby - pamiętnikarskim, epopeicznym wspominaniem jako punktem dojścia pewnej refleksji, wewnętrznej logiki dzieła, ostatnim ogniwem „dziedziczenia” szlacheckich wartości.

Wszystkie te odejścia sa przedstawione jako coś naturalnego, ale jednocześnie narrator poświęca wiele miejsca na opis przygotowania do śmierci i reakcji najbliższych na stratę. Ważne wydaje się też usytuowanie kolejnych refleksji żałobnych - na początku i na końcu ksiąg, jakby stanowić miały one dominantę kompozycyjną tekstu. Z opisów wyłania się wzór dobrej żałoby, która według Pola powinna polegać nie tyle na pogodzeniu się ze stratą, ile na wiecznym powrocie do tego, co utracone - powrocie w opowieści, zapiskach, wspomnieniu. Diariusz Rożanki to właśnie taki gest: ciagłego powracania do postaci ważnych w jego życiu; gest, który jednak nie przynosi ulgi, bo jak przekonuje utwór, ból po stracie - wbrew późniejszym teoriom psychologicznym - należy czuć zawsze i wobec każdego.

Patrzenie na świat $z$ perspektywy żałoby zmienia postrzeganie czasu i przestrzeni. Czas zatrzymuje się tak jak rzymski zegar hetmana, symbol całego uniwersum chrześcijańsko-szlacheckiego. Żałobnik zmaga się z upływem chwil; oddalenie od momentu straty łagodzi tylko ucieczka we wspomnienia. Żałobnikowi czas przeszły wydaje się wartością, a czas przyszły nabiera wartości tylko przez umacnianie wizerunku zmarłych. W świecie zaczynają znaczyć miejsca, które wiążą się ze stratą - dla Rożanki to Sandomierz, ojcowizna czy Ziemia Święta. Ostatecznie z podmiotowością żałobnika zaczyna się dziać coś dziwnego. Przytłumiona słowami tych, którzy odeszli, nie ma ona szansy na rozwój. Opłakujący stratę szuka ukojenia swojego bólu w zejściu do grobów, bo paradoksalnie jest to jedyne miejsce, gdzie może toczyć się życie.

Jak sądzę, ta swoista postawa żałobnika to trzeci z kluczy interpretacyjnych, który pozwala zrozumieć późną twórczość Pola, a zwłaszcza jego podejście do tradycji. W tym okresie twórca porządkował własne dzieła, publikował teksty powstałe w przeszłości, podsumowywał swoje osiaggnięcia i porażki, posługiwał się pojęciem

77 Fragment ten ukazał się w „Kółku Rodzinnym” i w „Bibliotece Warszawskiej”, co pokazuje, że jako główny temat utworu zapowiadano nie życie hetmana, tylko jego śmierć i przeżywanie żałoby.

78 Pol, Pacholę hetmańskie, t. 2, s. 9. 
„najnowszej tradycji narodu”, w którego zakres wchodziły przecież dzieła pochodzące $z$ ostatnich lat jego życia, także - jak można przypuszczać - jego własne. Uznanie się za część „najnowszej tradycji narodu” oznacza przecież, że patrzy się na siebie jak na osobę, która już do świata nie należy, która oddziałuje, ale jakby należała do przeszłości, spoczywała w mogile rodzącej życie.

W tym zamknięciu się w grobie nie chodzi bowiem o mesjanizm, zbawienie poprzedzone cierpieniem czy ofiara, nie idzie o otwarcie perspektywy eschatologicznej, nawet jeśli to $z$ wielkich idei romantycznych Pol czerpie metaforykę. Tradycjonalizm poety nie oznacza też naiwnego hołdowania przeszłości, a postępowość - prostodusznej wiary w cywilizacyjne czy duchowe zbawienie. Łączenie tych skrajnych perspektyw w figurze Janusa ${ }^{79}$ było przejawem niezwykle współczesnej postawy, świadomego uczestnictwa w teraźniejszości, przywiązania do tego, co wartościowe z punktu widzenia epickiego, narodowego „dziś”, ale też postawy szukającej nowego życia i idealnego wzoru w geście żałobnego upamiętniania, w oczekiwaniu na własną śmierć. Intelektualne przygody Pola rozgrywały się pod koniec jego życia w żywiole epopei.

\author{
Abstract \\ DAMIAN WŁODZIMIERZ MAKUCH University of Warsaw \\ ORCID: 0000-0002-9488-5035
}

THE IDEA OF MOURNING EPIC POEM WINCENTY POL'S LATE WORK IN THE LIGHT OF “PACHOLE HETMAŃSKIE” ("HETMAN’S INFANT”)

The author of the article presents the late work of Wincenty Pol in a new light, and his starting point is the forgotten poem Pachole hetmańskie (Hetman's Infant). He analyses the poet's statements and compares them with the negative opinions of critics and modern researchers in order to prove that for Pol the work had a critical meaning in three dimensions: idealistic perception of art (and culture), the author's search for a contemporary diarist epic poem, and his own attitude towards the newest tradition of the nation characterized by mourning of the past. Therefore, the article explains late works of Pol as well as introduces a forgotten part of metaliterary reflection of the 1860s. polskiej XIX wieku, która jedną twarzą i duchem narodowych tradycji spogląda w przeszłość okiem starca, a drugą twarza patrzy w przyszłość nadzieja promienną młodzieńca”. 